\author{
Karolina Domagalska-NowaK \\ Uniwersytet im. Adama Mickiewicza \\ $w$ Poznaniu
}

\title{
EDUKACJA RELIGIJNA W NORWEGII
}

\begin{abstract}
Aвstract. Domagalska-Nowak Karolina, Edukacja religijna w Norwegii [Religious Education in Norway]. Studia Edukacyjne nr 50, 2018, Poznań 2018, pp. 351-368. Adam Mickiewicz University Press. ISSN 1233-6688. DOI: 10.14746/se.2018.50.23

The nature of religious education in Norwegian schools has been conditioned by the relationship between the state and the church. Hence the question: "Does Norway guarantee freedom of thought, belief and religion?" The main aim of the paper is to analyze the changes in the relationships between the state and the church, the state and religion as well as the location of Religious Education in Norwegian schools in the historical, juridical, social, and political context. The aims and scopes of religious education together with curricula in the comprehensive schools seem to be exceptional among European states. The social changes, including immigration from states with a different cultural background, and the rise of the humanities impact the changes in Norway and the Norwegian Church.
\end{abstract}

Key words: religious education, Church of Norway

Edukacja religijna we współczesnych społeczeństwach realizowana jest na różnych polach, zarówno prywatnym (w rodzinie), jak i zinstytucjonalizowanym (związki wyznaniowe, szkoły). Szkolna edukacja religijna może przybierać formy w zależności od celu i funkcji oraz kontekstu społecznego. W Europie wprowadzenie nauczania religijnego jako przedmiotu obowiązkowego miało miejsce $w$ końcu XVIII wieku ${ }^{1}$. A. Różańska wskazuje, że edukacja religijna w społeczeństwach, które były homogeniczne pod względem kulturowym i religijnym była elementem, $\mathrm{w}$ którym koncentrowały się wspólne ideały i wskazówki moralne ${ }^{2}$. W krajach o dominującej jednej religii istnieje tendencja do zawłaszczania i narzucania norm większości. W tym przypadku

${ }^{1}$ J. Bagrowicz, Edukacja religijna wspótczesnej młodzieży. Źródła i cele, Torun 2000, s. 32.

2 A. Różańska, Edukacja religijna młodzieży w warunkach pluralizmu religijnego w wybranych krajach Europy Środkowo-Wschodniej (Grupa Wyszehradzka: Polska, Czechy, Stowacja, Wegry) - studium porównawcze, Torun 2015, s. 109. 
mamy do czynienia z zagrożeniem dla wolności religijnej i wyznaniowej grup mniejszościowych, nie tyle przez normy prawne, co praktykę. Od lat 80. XX wieku pojawiają się inicjatywy na rzecz współistnienia i tolerancji religijnej w postaci wspólnych modlitw wyznawców różnych religii $(1986,2002)$, które nie są postrzegane jako zagrożenie dla wiary i tożsamości ${ }^{3}$.

W państwach europejskich można wyróżnić różnorodne podejście do edukacji religijnej, uwzględniające istnienie mniejszości religijnych: edukacja religijna niekonfesyjna (ponadkonfesyjna, ekumeniczna) lub model otwarty dla wszystkich uczniów ${ }^{4}$. Wybór określonego modelu wynika z tradycji i polityki państwa. Nie bez znaczenia są tu również mono/wielokulturowość/ wielowyznaniowość społeczeństwa, gotowość do społecznej i politycznej akceptacji innych wyznań ${ }^{5}$.

A. Różańska wyróżnia następujące modele i formy organizacyjno-dydaktyczne edukacji religijnej w europejskich systemach edukacyjnych:

- konfesyjno-katechumenalny (tradycjonalistyczny, kerygmatyczny) obowiązuje między innymi w Grecji, Bułgarii, Rumunii, Polsce, Łotwie, na Węgrzech;

- konfesyjno-dialogiczny (otwarty) - funkcjonuje między innymi w większości landów niemieckich;

- ponadkonfesyjny, ekumeniczny - znajduje zastosowanie między innymi w Danii, Holandii;

- studyjny, religioznawczy - bez udziału wspólnot religijnych, można go obserwować między innymi w Anglii, Szwecji, Walii;

- laicko-demokratyczny - stosowany między innymi w Hiszpanii (gdzie do wyboru jest nauka konfesyjna rzymskokatolicka lub laicko-demokratyczne religioznawstwo);

- brak edukacji religijnej w systemie szkolnym lub jej forma szczątkowa obowiązuje między innymi we Francji, Estonii, Republice Czeskiej6.

Niemal do końca XX wieku w Norwegii realizowano konfesyjny model edukacji religijnej, jednak $\mathrm{w}$ wyniku wieloetapowych zmian wprowadzono edukację religijną niekonfesyjną, opartą na wartościach chrześcijańskich, z których wyrastają wartości społeczeństwa norweskiego.

Norwegia - bogaty gospodarczo kraj, nienależący do Unii Europejskiej, ma silną identyfikację narodową. Stabilny sektor publiczny historycznie oparty jest na socjaldemokratycznej polityce socjalnej i wartościach egalitarnych.

${ }^{3}$ E. Sakowicz, Wychowanie w kulturach i religiach świata, [w:] Dzieci z trudnościami adaptacyjnymi w młodszym wieku. Aspekty rozwojowe i edukacyjne w kontekście specyfiki różnic kulturowych, red. E. Śmiechowska-Petrovska, Warszawa 2016, s. 67-100.

${ }^{4}$ Por. A. Różańska, Edukacja religijna, s. 109-112.

5 Por. tamże, s. 116-129.

${ }^{6}$ Por. tamże, s. 119-129. 
Od końca XX wieku można zaobserwować dynamiczne zmiany w społeczeństwie kraju fiordów spowodowane napływem migrantów zarówno z krajów europejskich, jak i azjatyckich oraz afrykańskich.

Struktura grupy imigrantów w Norwegii jest niezwykle zróżnicowana pod względem kraju pochodzenia. Imigranci w Norwegii są w dużej mierze Europejczykami i Azjatami (por. tab. 1).

Tabela 1

Imigranci w Norwegii według grup wiekowych. Grupy powyżej 10000 osób

\begin{tabular}{|l|c|c|c|c|c|c|}
\hline $\begin{array}{c}\text { Kraj } \\
\text { pochodze- } \\
\text { nia/wiek }\end{array}$ & Łącznie & $0-5$ lat & $6-15$ lat & $16-19$ lat & $20-66$ lat & $\begin{array}{c}\text { Ponad } \\
66 \text { lat }\end{array}$ \\
\hline & 514735 & 7021 & 36452 & 20270 & 426711 & 24281 \\
\hline Polska & 97196 & 1384 & 7046 & 2610 & 85224 & 932 \\
\hline Litwa & 37638 & 533 & 3229 & 1128 & 32683 & 65 \\
\hline Szwecja & 36315 & 320 & 939 & 323 & 31131 & 3602 \\
\hline Somalia & 28696 & 256 & 3822 & 2523 & 21608 & 487 \\
\hline Niemcy & 24601 & 273 & 1497 & 1014 & 19256 & 2561 \\
\hline Irak & 22493 & 132 & 1240 & 1246 & 19375 & 500 \\
\hline Syria & 20823 & 1625 & 4296 & 1543 & 13239 & 120 \\
\hline Filipiny & 20537 & 114 & 1243 & 643 & 18030 & 507 \\
\hline Pakistan & 19973 & 178 & 626 & 377 & 17096 & 1696 \\
\hline Erytrea & 19957 & 224 & 2380 & 1822 & 15350 & 181 \\
\hline Dania & 19494 & 199 & 635 & 246 & 13443 & 4971 \\
\hline Tajlandia & 18634 & 81 & 1550 & 1291 & 15566 & 146 \\
\hline Rosja & 17225 & 109 & 1327 & 830 & 14307 & 652 \\
\hline Iran & 17169 & 79 & 921 & 609 & 14851 & 709 \\
\hline $\begin{array}{l}\text { Afgani- } \\
\text { stan }\end{array}$ & 15986 & 156 & 1770 & 2464 & 11321 & 275 \\
\hline $\begin{array}{l}\text { Wielka } \\
\text { Brytania }\end{array}$ & 14330 & 269 & 625 & 141 & 10521 & 2774 \\
\hline Rumunia & 13889 & 192 & 974 & 289 & 12304 & 130 \\
\hline Wietnam & 13750 & 71 & 186 & 131 & 12276 & 1086 \\
\hline $\begin{array}{l}\text { Bośnia } \\
\text { i Hercego- } \\
\text { wina }\end{array}$ & 13591 & 58 & 171 & 135 & 11776 & 1451 \\
\hline Turcja & 11330 & 164 & 231 & 162 & 10275 & 498 \\
\hline Indie & 11022 & 411 & 579 & 111 & 9270 & 651 \\
\hline
\end{tabular}




\begin{tabular}{|l|l|r|r|r|r|r|}
\hline Łotwa & 10052 & 161 & 973 & 268 & 8602 & 48 \\
\hline Kosowo & 10034 & 32 & 192 & 364 & 9207 & 239 \\
\hline
\end{tabular}

Stan na: 1.01.2017 rok$^{7}$.

Pod względem historycznym, kulturowym i prawnym Norwegia postrzegana jest jako państwo chrześcijańskie, a pod względem społecznym - jako państwo w dużej mierze zlaicyzowane. Jednakże, w kraju tym dopiero na początku XXI wieku rozpoczęto formalne rozdzielanie państwa od Kościoła8.

Głębokie reformy dążące do rozdziału państwa od Kościoła rozpoczęły się (dopiero) w 2008 roku, kiedy zawarto tak zwaną ugodę kościelną, która doprowadziła do przyjęcia przez parlament (Storting) w maju 2012 roku ustaw zmieniających pozycję Norweskiego Kościoła Państwowego. Luterański Kościół Norwegii, kościół państwowy od 1814 roku, to jest od uzyskania niezależności Norwegii od Danii, stał się samodzielny. Reformy wymagały zmiany obowiązujących zapisów konstytucji. Oficjalnym zwierzchnikiem kościoła luterańskiego był król, jednocześnie zobowiązany do przynależności właśnie do kościoła luterańskiego. Biskupi i proboszczowie byli mianowani na poziomie parlamentu norweskiego. Na początku XX wieku wprowadzono regułe - w celu zapewnienia stabilności kościołowi luterańskiemu w Norwegii - iż połowa składu rządu miała być wyznania luterańskiego. Nowe przepisy (wprowadzone w roku 2012) uznają równość religii i tolerancję wobec innych. Wcześniej wolność religijna obejmowała wszystkich poza monarchą, który jak już wcześniej wspomniano był głową kościoła państwowego. Od 1 stycznia 2017 roku duchowni luterańscy przestali mieć status urzędnika państwowego, a Rady Duszpasterskie nie należą już do administracji rządowej. Najwyższą władzę w tym kościele sprawuje Synod. Na mocy zmian w przepisach, wszystkie wyznania mają również prawa i status 9 .

Do Kościoła Norweskiego (Den norske kirke) należy około $80 \%$ populacji, przy czym aktywnie praktykuje zaledwie kilka procent, natomiast $17 \%$ uczestniczy w spotkaniach religijnych przynajmniej raz w miesiącu. Do Kościoła należy wyższy odsetek kobiet (59\%) niż mężczyzn (50\%). Istnieje również wyraźna korelacja między religią a wiekiem ${ }^{10}$. W grupie wiekowej 15-24

7 T. Sandnes (red.), Innvandrere i Norge 2017, Oslo - Kongsvinger 2017, [dostęp: 15.12.2017] https://www.ssb.no/en/befolkning/artikler-og-publikasjoner/_attachment/332154? ts $=1604 \mathrm{a} 8 \mathrm{c} 12 \mathrm{~b} 0 \mathrm{~s} .20$.

${ }^{8}$ H.K. Sødal, L.G. Eidhamar, Religion in Norway, A bird's-Eye View, [w:] Norway. Society and Culture, wyd. II, red. E. Maggerø, B. Simonsen, Kristiansand 2008., s. 74-92.

${ }^{9}$ J. Gunnarsson Gunnar, From religious homogeneity to secularization, diversity and pluralism, Nordidactica, 2017, 1, s. 1-26; C.M. Jacobsen, Norway, [w:] Islam in the Nordic and Baltic Countries, red. G. Larsson, London 2009, s. 18-39.

${ }^{10}$ Tamże. 
tylko 25\% wierzy w Boga. Wśród osób liczących 60 lat lub więcej 48\% deklaruje wiarę $\mathrm{w}$ Boga ${ }^{11}$. Dla porównania: w 2008 roku 44\% zapytanych twierdziło, że wierzy w Boga, a 57\% miało wątpliwości lub w Boga nie wierzyło. Jedna osoba na trzy wierzyła $w$ życie po śmierci ${ }^{12}$. W ważnych ceremoniach, w postaci udzielanych chrztów, ślubów, ceremonii pochówku, odnotowywany jest systematyczny spadek (patrz tab. 2). Według badań opinii publicznej z 2016 roku, 41\% kobiet i 32\% mężczyzn wierzy w Boga. Najniższy wskaźnik występuje w Oslo (29\%), a najwyższy - w zachodniej Norwegii, w Vest-Agder $(44 \%)$. Co ciekawe, kiedy do członków norweskiego Kościoła padają pytania o ich związek z religią, mniej niż połowa - $48 \%$ twierdzi, że postrzegają siebie jako chrześcijan, 33\% uważa się za ateistów, a 14\% wierzy w twórcę niezależnego od religii, natomiast $5 \%$ nie wie. Dla wielu Kościół oznacza tylko tradycję i kulturę ${ }^{13}$. Badanie przeprowadzone przez TNS Gallupa na rzecz Stowarzyszenia Humanistycznego w 2016 roku pokazuje również, że 58\% osób uważa, że podstawową wartością państwa powinna być demokracja, praworządność i poszanowanie praw człowieka. Niemniej jednak $12 \%$ sądzi, że podstawą państwa powinno być chrześcijańskie i humanistyczne dziedzictwo, a 22\% pragnie zarówno wartości demokratycznych, jak i chrześcijańskich ${ }^{14}$.

Tabela 2

Kościół Norweski ${ }^{15}$

\begin{tabular}{|l|c|c|}
\hline & 2016 & Zmiana w ciągu 4 lat \\
\hline Członkowie Kościoła Norweskiego & 3758070 & -90225 \\
\hline $\begin{array}{l}\text { Członkowie Kościoła Norweskiego } \\
\text { - procentowy udział w populacji }\end{array}$ & $71,50 \%$ & $-4,70 \%$ \\
\hline Chrzty & 32561 & -5796 \\
\hline $\begin{array}{l}\text { Procentowy udział chrztów wzglę- } \\
\text { dem liczby urodzeń }\end{array}$ & $55,30 \%$ & $-8,40 \%$ \\
\hline Pochówki kościelne & 36150 & -1523 \\
\hline $\begin{array}{l}\text { Liczba pochówków kościelnych } \\
\text { względem liczby zmarłych }\end{array}$ & $88,80 \%$ & $-1 \%$ \\
\hline Śluby kościelne & 7535 & -1363 \\
\hline Inne usługi kościelne & 99929 & -6109 \\
\hline
\end{tabular}

${ }^{11}$ https://www.vl.no/nyhet/forste-gang-flertall=-tror-ikke-pa-gud1-702540.?paywalltrue [dostęp: 11.05.2018].

12 https://www.dt.no/kultur/nyheter/troen-pa-gud-dor-langsomt-ut/s / 2-2.1748 -1.5145740 [dostęp: 11.05.2018].

${ }^{13}$ https:// widget-last-free-article.herokuapp.com/?desktop=true [dostęp: 11.05.2018].

${ }^{14}$ https://www.dagbladet.no/kultur/gud-som-valgflesk/68533849 [dostęp: 10.04.2018].

${ }_{15}$ Church of Norway, https://www.ssb.no/en/kultur-og-fritid/statistikker/kirke_kostra [dostęp: 10.04.2018]. 


\begin{tabular}{|l|c|c|}
\hline $\begin{array}{l}\text { Liczba osób korzystających z usług } \\
\text { Kościoła Norweskiego }\end{array}$ & 5685138 & -331880 \\
\hline $\begin{array}{l}\text { Procentowy udział osób } \\
\text { korzystających z usług kościelnych }\end{array}$ & 90,9 & $-1,8$ \\
\hline
\end{tabular}

Na początku 2017 roku niemal 620000 osób było członkami społeczności religijnych i humanistycznych innych niż Kościół Norweski (Norweskie Towarzystwo Humanistyczne, Ruch Zielonoświątkowców, wyznawcy islamu, Kościoła rzymskokatolickiego, Wolnego Kościoła Luterańskiego, Metodyści i inni - por. tab. 3). W grupie tej wyróżniają się chrześcijanie - niemal 55\% (z przewagą wyznania rzymskokatolickiego), różne społeczności islamskie - około $24 \%$ członków, podczas gdy członkowie społeczności buddyjskich stanowili 3\%, a Humaniści i inne religie - odpowiednio 15\% i 2,6\% członków. W sumie 12\% mieszkańców stanowili członkowie wspólnot religijnych i życiowych poza Kościołem Norwegii - stan na dzień 1 stycznia 2017 roku. Jest to wzrost z 10,8\% w roku 2015. Jedynie 6,2\% osób nie należy do żadnej wspólnoty.

Tabela 3

Członkowie wspólnot religijnych i związków humanistycznych poza Kościołem Norweskim, którzy otrzymali dotację rządową

\begin{tabular}{|l|c|c|c|c|}
\hline \multirow{2}{*}{} & \multicolumn{2}{|c|}{2017} & \multicolumn{2}{c|}{ Zmiany procentowe } \\
\cline { 2 - 5 } & członkowie & procent & $2016-2017$ & $2013-2017$ \\
\hline \multirow{2}{*}{ Łącznie } & 619222 & 100 & $-0,5$ & 12,7 \\
\hline Bahaizm, bahá'í & 1146 & 0,2 & $-0,3$ & 2,1 \\
\hline Buddyzm & 17351 & 2,8 & $-7,8$ & 8,4 \\
\hline Hinduizm & 8965 & 1,4 & 0,9 & 31,9 \\
\hline Islam & 153067 & 24,7 & 3,3 & 26,6 \\
\hline Judaizm & 769 & 0,1 & $-0,1$ & $-2,4$ \\
\hline Chrześcijanie & 339492 & 54,8 & $-2,7$ & 8,5 \\
\hline Sikhizm & 3654 & 0,6 & 3,1 & 10 \\
\hline Humaniści & 92919 & 15 & 3,5 & 8 \\
\hline $\begin{array}{l}\text { Inne religie i związki huma- } \\
\text { nistyczne }\end{array}$ & 1859 & 0,3 & 0,5 & 23,9 \\
\hline
\end{tabular}

Stan na: 1.01.2017 rok $^{16}$.

${ }^{16}$ Religious communities and life stance communities, https://www.ssb.no/en/kultur-og-fritid/statistikker/trosamf [dostęp: 11.05.2018]. 
W Norwegii obowiązuje rejestracja w związku wyznaniowym lub w Unii Humanistyczno-Etycznej, która w konsekwencji wpływa na finansowanie organizacji ze źródeł publicznych. W przypadku braku rejestracji mieszkańca Norwegii, władze automatycznie przypisują osobę do Kościoła Norweskiego. Jakkolwiek po reformach z 2012 roku Narodowy Kościół Norwegii oficjalnie jest niezależny od państwa, to nadal jednak pozostaje uzależniony od wsparcia finansowego $\mathrm{z}$ budżetu.

Charakterystyczną cechą norweskiego szkolnictwa podstawowego jest ważna rola przypisywana chrześcijaństwu. Historycznie rzecz biorąc, obowiązkiem publicznych szkół podstawowych było nauczanie religii. Edukacja religijna $\mathrm{w}$ norweskich szkołach publicznych jest tematem spornym. Norwegia wybrała model wychowania religijnego, w którym religia jest zwyczajnym przedmiotem dla wszystkich uczniów, niezależnie od ich religii i światopoglądu. W ostatnich latach wpływ chrześcijaństwa został utrwalony w tym sensie, że norweskie tradycje i korzenie zdefiniowano jako chrześcijańskie. Uprawomocnia to znaczenie, jakie przypisuje się chrześcijaństwu w szkołach publicznych. Zakres obowiązkowej chrześcijańskiej edukacji w kontekście wielokulturowym był negocjowany, w szczególności w latach 1997-2008. W publicznej narracji stosowane są pojęcia "nasza historia” oraz "nasze chrześcijańskie i humanistyczne tradycje”, bez dostrzegania faktu, że nie wszyscy obywatele mieli wspólną historię. Ci, którzy nie podzielali tej założonej wspólnej tradycji, byli wyłączeni z narodowej podstawy programowej do 1997 roku $^{17}$.

Norweska edukacja religijna musi być rozpatrywana w kontekście norweskiego systemu szkolnego i jego historii. Zdaniem Oddrun M.H. Bråtena, procesy sekularyzacji, pluralizmu i globalizacji znalazły odzwierciedlenie w programie nauczania religii ${ }^{18}$. Norweska edukacja religijna jest centralną, integralną i integrującą częścią Norweskiego Programu Narodowego ${ }^{19}$. Religia odgrywała bardzo dużą rolę w społeczeństwie norweskim. Jednak w ciągu kilku minionych dekad - podobnie jak w większości krajów zachodnich - ten obszar wydaje się mniej ważny społecznie niż wcześniej. Helje Kringlebotn Sødal i Levi Geir Eidhamar dzielą historię religii w Norwegii na trzy okresy:

- pierwszy okres przedchrześcijański z religią nordycką do około 1000 roku;

- okres chrześcijański do ostatnich dziesięcioleci dwudziestego wieku;

17 P. Joron, Etno-Nationalizm and Education, [w:] Paradoxes of Cultural Recognition. Perspectives from Northen Europe, red. S.A. Sharam, E.Th. Hylland, G. Halleh, Burlington 2009, s. 114-115.

${ }_{18}$ M.H. Bråten Oddrun, Towards a Methodology for Comparative Studies in Religious Education. A Study of England and Norway, Münster, New York - München - Berlin 2013, s. 113.

19 Tamże, s. 102. 
- współczesny pluralistyczny okres chrześcijański, gdzie różne religie i poglądy świeckie istnieją przy wciąż dominującej religii chrześcijańskiej ${ }^{20}$.

Wiedzę o wierzeniach z pierwszego okresu czerpie się z relacji autorów chrześcijańskich, zapisanych kilka stuleci po nawróceniu na chrześcijaństwo oraz ze źródeł materialnych ${ }^{21}$. W pierwszym okresie Wikingowie, przodkowie Norwegów, wierzyli w wielu bogów o nadludzkich mocach. Bóstwa były mądre, odważne i śmiertelne. Nadludzkie moce nie przeszkadzały przypisywaniu im różnych słabości. Epokę Wikingów umownie otwiera rok 793, kiedy skandynawscy piraci zdobyli i splądrowali klasztor Lindisfarne. Pogański okres działań Wikingów kończy bitwa pod Hastings w 1066 roku. Chrystianizacja Norwegii trwała około 200 lat i była związana z kontaktami Norwegów z chrześcijańską Europą (w celach handlowych oraz rozbójniczych), stanowiąc dzieło nawróconych i ochrzczonych w Anglii Wikingów. Pierwszym królem chrześcijańskim w latach 933-961 był, ochrzczony w Anglii, Haakon Dobry (Adalsteinsfostre). Sprowadził on do Norwegii księży z Anglii i wznosił świątynie. Ostateczną stabilizację chrześcijaństwa przyniosły rządy króla Olafa II Haraldssona ${ }^{22}$ w latach 1016-1028, który jako najpopularniejszy Wiking został wyniesiony na ołtarze. Miejsce jego pochówku w Trondheim było celem pielgrzymek. Chrześcijaństwo w Norwegii, podobnie jak w Polsce, towarzyszyło umacnianiu władzy królewskiej. Dwa jego nurty, rywalizujące o wpływy: rzymskokatolicki z papieżem w Rzymie i grekokatolicki z patryjarchą w Bizancjum, doprowadziły do dominacji w Norwegii tego pierwszego. Luterański Kościół Norwegii (tradycji ewangelicko-augsburskiej) istnieje od XVI wieku, kiedy to w 1537 roku luteranizm został ustanowiony oficjalną religią Norwegii. Ze względu na szczególne konstytucyjne ułożenie kościoła państwowego, problemy religii i polityki w tym kraju były często bezpośrednio związane z rolą państwa ${ }^{23}$.

Wiek XVIII to czas budowy państwa, a ważnym aspektem tego procesu było ustanowienie wspólnego kanonu religijnego. Kiedy w 1739 roku wprowadzono w Norwegii powszechne nauczanie przez rządzącego w niej króla duńskiego, była to bardziej zasada niż praktyka. Jednakże, powołano wówczas pierwsze szkoły dla „zwykłych ludzi”, a nauczyciele wędrowali między gospodarstwami, prowadząc lokalną szkołę przez kilka tygodni, by następnie przemieścić się na kolejne miejsce w tym ubogim wówczas kraju na peryferiach Europy. Ten pierwszy system szkolny został wprowadzony w ramach protestanckiego kościoła państwowego, a celem była edukacja pu-

\footnotetext{
${ }^{20}$ H.K. Sødal, L.G. Eidhamar, Religion in Norway, s. 74.

${ }^{21}$ E. Roesdahl, Historia Wikingów, Gdańsk 1996, s. 133.

22 A. Mańkowska, Religia w Norwegii.

${ }^{23}$ G. Skeie, Diversity and the political function of religious education, British Journal of Religious Education, 2006, 28(1), s. 19-32.
} 
bliczna, ucząca umiejętności czytania i pisania ${ }^{24}$ oraz poznania podstaw religii luterańskiej ${ }^{25}$. Warto wspomnieć, że komentarz Erica Pontoppidana do katechizmu miał kluczowy wpływ na sposób postrzegania siebie jako obywateli. W roku 1747 został on biskupem Bergen, gdzie wprowadził wiele reform w edukacji i napisał Historię naturalna Norwegii (Versuch einer natürlichen Geschichte Norwegens, Kopenhaga 1752-1753) ${ }^{26}$.

System nauczania trwał mniej więcej przez pierwsze 150 lat nieprzerwanie, aż do włączenia Norwegii do związku rządzonego przez Szwecję w 1814 roku. Można uznać, że wszystkie publiczne szkoły w tym czasie były religijne ${ }^{27}$. Wiek XIX to wiek sekularyzacji i pluralizacji szkoły. Kształcenie religijne stało się bardziej przedmiotem szkolnym, nawet jeśli celem było pielęgnowanie wiary chrześcijańskiej w interpretacji luterańskiego kościoła państwowego. W tym czasie w Norwegii dokonywały się silne zmiany polityczne, łącznie z walką o niepodległość narodową ze Szwecją, o system demokratyczny oraz parlamentarny i tym podobne. Około roku 1850 państwo zezwoliło wyznawcom innych religii niż religia luterańska organizować nauczanie, a nauczyciele mogli być zwolnieni z nauczania religii. Mniejszości religijne były widoczne, ale bardzo małe w porównaniu z luterańską większością ${ }^{28}$. W 1889 roku pojawiły się pierwsze nowoczesne prawa szkolne. System szkolny ewoluował w kierunku bardziej powszechnego systemu w miastach i na wsi, a wychowanie religijne pozostawało pod kontrolą Kościoła. W Norwegii w XIX wieku, odmiennie niż w innych krajach, nie było rozróżnienia między wysoką kulturą europejską wspólną dla elit a kulturą ludową. Wyłaniająca się idea narodowa Norwegii stanowiła mieszankę tych dwóch obszarów. Chrześcijaństwo odgrywało ważną rolę zarówno w środowisku konserwatywnym, jak i liberalnym. Rządzący w Norwegii twierdzili, że reprezentują wiarę ludu lepiej niż Kościół, który był postrzegany jako elitarny i konserwatywny ${ }^{29}$. W połowie lat 30 . XX wieku uczniowie mieli prawo być zwolnieni z nauczania religii, jeśli nie byli członkami kościoła państwowego. W tym czasie podstawa programowa dla norweskiego systemu szkolnego była mocno oparta na zasadach socjaldemokracji, na ideale wspólnej szkoły dla wszystkich. Głównym celem było zabezpieczenie ogółu ludzi żyjących w słabo zaludnionym kraju i pochodzących z różnych grup społecznych (każdy miał mieć szansę na dobre wykształcenie) $)^{30}$.

\footnotetext{
${ }^{24}$ http://www.evrel.ewf.uni-erlangen.de/pesc/ie-2008-skeie.pdf

25 E. Roesdahl, Historia Wikingów.

26 https://www.britannica.com/biography/Erik-Pontoppidan

${ }^{27}$ http://www.evrel.ewf.uni-erlangen.de/pesc/ie-2008-skeie.pdf

28 Tamże.

29 Tamże.

30 Tamże.
} 
Z biegiem lat większość partii politycznych w Norwegii zaakceptowała główny kierunek demokratycznej polityki opartej na opiece społecznej, względnie egalitarnej gospodarce i polityce równości. Nawet jeśli Norwegia zgodnie z socjologią religii jest krajem wysoce zsekularyzowanym, państwo - Kościół odgrywa ważną rolę w niektórych rytuałach życia, wydarzeniach publicznych oraz czasach kryzysu na poziomie krajowym i lokalnym. W niektórych częściach kraju świeckie ruchy kościelne są nadal silne. Niezwykle trudne dla mniejszości religijnych jest uzyskanie realnego wpływu poza regionem Oslo. Mniejszości narodowe, etniczne i religijne są marginalizowane. Marginalizacja ta jest nieco przeciwna silnym ideałom wywodzącym się z tradycji labourzystowskiej i wspierana przez chrześcijańskie cnoty, aby rozpowszechniać bogactwo, dobra, wpływy i edukację dla wszystkich, niezależnie od pochodzenia czy grupy społecznej. Choć z drugiej strony, wszystkie oficjalnie uznane grupy religijne w Norwegii otrzymują obecnie rządowe dotacje na rzecz wspierania dzieci $\mathrm{w}$ ich społeczności wyznaniowej zgodnie z członkostwem. Dotyczy to również Norweskiego Stowarzyszenia Humanistów ${ }^{31}$.

Edukacja religijna w szkołach państwowych do 1969 roku stanowiła wprowadzenie do wiary norweskiego kościoła państwowego. Alternatywy dla szkół państwowych praktycznie nie istniały. Do roku 1969 tylko luterańscy chrześcijanie mogli nauczać religii (tj. chrześcijaństwa) w publicznych szkołach podstawowych. Wielu nie-luterańskich uczniów skorzystało z długo ugruntowanego prawa do rezygnacji w uczęszczaniu na lekcje religii. W 1969 roku Parlament po raz pierwszy oficjalnie zdecydował, że nauka religii w szkole („Wiedza o chrześcijaństwie”) powinna być postrzegana jako przedmiot szkolny, a nie jako część chrześcijańskiego wychowania. Symbolicznie przyjmuje się to za kolejny etap. Kilka lat później wprowadzono równoległy przedmiot szkolny dla tych, którzy byli zwolnieni z głównej edukacji religijnej. System z przedmiotami równoległymi oznaczał, że uczniowie, którzy zwykle należeli do tej samej klasy, byli oddzieleni w edukacji religijnej, a niektórzy zwolnieni z obu alternatyw ${ }^{32}$. Tylko ci, którzy nie byli członkami Kościoła Norwegii, mieli prawo wybrać niekonfesyjne zajęcia lub całkowicie zrezygnować z edukacji religijnej w szkole. Na poziomie szkoły ponadpodstawowej od dawna obowiązkowy był bardziej neutralny przedmiot "Religia i etyka"33. Zatem, rodzice odnośnie religii w szkole mieli do wyboru trzy opcje: (1) chrześcijaństwo z konfesją, luteranizm; (2) „światopoglądy” o charakterze neutralnym lub nawet świeckim; (3) brak edukacji religijnej lub światopoglądowej w szkole. Zasadniczo wspólnoty wyznaniowe mogą

\footnotetext{
31 Tamże.

32 Tamże.

${ }^{33}$ http://folk.uio.no/leirvik/OsloCoalition/Leirvik0902.htm
} 
ustanowić własną edukację religijną w szkole, ze wsparciem finansowym ze strony władz. Niektóre meczety skorzystały z okazji i dzięki temu mogły otrzymać wsparcie finansowe dla swoich szkół koranicznych (tylko dla tych muzułmańskich dzieci, które zrezygnowały z religii w szkole) ${ }^{34}$.

Skład społeczeństwa norweskiego uległ przemianie od wczesnych lat 70. XX wieku. Zwłaszcza w stolicy - Oslo Muzułmanie, Hindusi oraz wyznawcy innych religii byli bardziej widoczni w salach lekcyjnych, toteż potrzeby zmian w dziedzinie edukacji religijnej były oczywiste. Procesy sekularyzacji, pluralizacji i globalizacji można postrzegać jako ogólne tło dla ważnej zmiany w norweskiej edukacji religijnej, która miała miejsce w 1997 roku. Po okresie badań i debat politycznych szkolny przedmiot edukacji religijnej został zmieniony na przedmiot wieloaspektowy, przekazujący wszystkim uczniom wiedzę na temat chrześcijaństwa oraz innych światowych religii, etyki i filozofii. W pewnym stopniu było to połączenie dotychczasowych: chrześcijaństwa oraz przedmiotu dla wyznawców innych religii, ale stanowiło kontrowersyjny kompromis polityczny. Kościół Norwegii wyrażał akceptację, a mniejszości religijne czy świeccy humaniści byli bardzo krytyczni. Od roku 1969 do 1997 edukacja religijna w norweskich szkołach państwowych teoretycznie nie była wyznaniowa, ale praktycznie - wciąż wyznaniową edukacją chrześcijańską, kładąc nacisk na norweski luteranizm ${ }^{35}$. Wielu muzułmanów wyszło na ulice, aby demonstrować przeciwko nowemu obowiązkowemu przedmiotowi ${ }^{36}$. Byli podejrzliwi wobec pierwotnego projektu tematu („chrześcijaństwo plus”) i krytycznie odnosili się do idei przedmiotu obowiązkowego, w którym główny ciężar położony był na chrześcijaństwo. Interpretacja kontekstu kulturowego edukacji religijnej wydaje się wyjaśniać niektóre trendy rozwoju od 1997 roku, kiedy to wprowadzono program nauczania wielu przedmiotów. Zostało to zrobione w sposób, który nie ograniczał większości chrześcijańskiej. W tym programie chrześcijaństwo, które było przedstawione głównie jako wyznanie osobiste, przekonania, dążyło w kierunku bycia przedstawianym jako bogata tradycja kulturalna jednocząca wszystkich obywateli Norwegii. Było to do przyjęcia zarówno dla Kościoła Norwegii i bardziej zsekularyzowanego społeczeństwa. W 1993 roku Storting przyjął ważny dokument: Podstawowy Program Nauczania. Przygotowany przez Ministerstwo Edukacji, stanowił wyraźne dzieło ministra edukacji Gudmunda Hernesa. Był to istotny dokument, określający wartości i cele edukacyjne, do których powinna zmierzać cała edukacja w Norwegii, który z retoryką łączy i syntetyzuje wiele podejść oraz tradycji edukacyjnych. Podkreśla wartość pracy oraz działania na rzecz godności ludzkiej i rozwoju,

\footnotetext{
${ }^{34}$ Tamże.

${ }_{35}$ M.H. Bråten Oddrun, Towards a Methodology for Comparative Studies, s. 22-23.

${ }^{36}$ Por. H. Storhaug, Islam, Jedenasta plaga, Katowice 2015.
} 
znaczenie dzielenia się dziedzictwem kulturowym i miejscem religii w tym norweskim dziedzictwie. Nowy program Hernesa został wdrożony w 1997 roku, pod nazwą Identitet i Dialog (Tożsamość i Dialog). Grupa robocza zasugerowała, że program nauczania powinien obejmować kształcenie w zakresie chrześcijaństwa, nauczanie o poglądach życiowych i innych religiach. Autorzy Białej Księgi zasugerowali wspólny, konfesyjny przedmiot, który można uznać za religijne wychowanie. W 1995 roku Komisja przedstawiła Białą Księgę Stortingowi. Dokument ten prezentował pesymistyczne analizy kulturowe, argumentując, że młodzi ludzie w tamtym czasie byli zagrożeni rozwojem fragmentarycznych i rozproszonych tożsamości, ze względu na relatywistyczne, szybko rozwijające się presje postmodernistyczne ${ }^{37}$. Ponadto, idee pedagogiczne leżące u podstaw edukacji religijnej inspirowały się krytyką pozytywizmu. Humanistom i przedstawicielom mniejszości religijnych zaproponowano przedmiot, podczas którego poświęcano ponad 50\% czasu na nauczanie o chrześcijaństwie. Z punktu widzenia mniejszości przedmiot był jedynie „niewyznaniowy” deklaratywnie. Strona rządowa postrzegała go jednak jako kluczowy aspekt kształcenia tolerancyjnych obywateli na przyszłość - obywateli, którzy zostali wyedukowani, aby posiadać wiedzę i szacunek do własnych oraz innych religijnych tradycji ${ }^{38}$.

Ocena ta zaowocowała reformami programów nauczania kilka lat później, ale nadal to nie wystarczało, aby zadowolić mniejszości. Ponieważ treść programu nauczania nie była satysfakcjonująca, brak ogólnego prawa do zwolnienia stał się kluczową kwestią. Co ciekawe, świeccy humaniści składający się głównie z norweskiej populacji znaleźli alternatywną drogę do osiągnięcia wpływu, wykorzystując mniejszości religijne pochodzenia imigranckiego. Od roku 2001 grupa rodziców podjęła kwestie związane z nauczaniem religii w sądzie. Byli wspierani przez Norweskie Stowarzyszenie Humanistów. Rodzice przegrali jednak sprawy w norweskim systemie prawnym we wszystkich instancjach. Niektóre z nich były kontynuowane w Komitecie Praw Człowieka ONZ (Genewa) i przed Europejskim Trybunałem Praw Człowieka (Strasburg). W obu przypadkach (2004 i 2006) wygrali rodzice i rząd Norwegii musiał zmienić obowiązujący program oraz przepisy prawne. Zmiany te były dokonywane głównie w treściach programowych, które dały więcej miejsca niechrześcijańskim religiom i światopoglądom, podkreślając znaczenie obiektywności, bezstronności oraz neutralne nauczanie i informacje na temat zasad zwolnienia. Rozwój obecnej norweskiej edukacji religijnej stanowi konsekwencje ostatnich decyzji prawnych, opartych głównie na kwestiach zapewnienia respektowania praw człowieka ${ }^{39}$.

${ }^{37}$ L.L. Iversen, Learning to be Norwegian. A case study of identity management in religious education in Norway, New York - Munchen - Berlin 2012, s. 101.

38 Tamże, s. 101-104.

39 http://www.evrel.ewf.uni-erlangen.de/pesc/ie-2008-skeie.pdf 
Preambuła do norweskiej Ustawy o oświacie („formålsparagrafen”) do 2008 roku zawierała następujące informacje o edukacji szkolnej (jako takiej):

Celem kształcenia podstawowego i gimnazjalnego jest, w porozumieniu i we współpracy z rodziną, pomoc uczniom $\mathrm{w}$ wychowaniu chrześcijańskim i moralnym, rozwijaniu swoich zdolności umysłowych i fizycznych oraz dawać im dobrą wiedzę ogólną, aby mogli stać się użytecznymi i niezależnymi istotami ludzkimi w rodzinie i społeczeństwie.

Pragnę podkreślić, że dotyczyło to edukacji w Norwegii w ogóle, a nie jedynie w edukacji religijnej. Odniesienie do religii zostało usunięte po sugestiach Komitetu Praw Człowieka ONZ. Chodzi przede wszystkim o zwrot "pomagającą uczniom wychowywać się chrześcijańsko i moralnie", co jest kontrowersyjne $\mathrm{w}$ stosunku do szkolnego nauczyciela wielokulturowego, a także w odniesieniu do tego, czy KRL (Kristendoms- religions- og livssynskunnskap) można nazwać integracyjnym przedmiotem szkolnym ${ }^{40}$.

Nowy przedmiot edukacji religijnej w Norwegii zmienił się wielokrotnie od czasu jego wdrożenia.

1. Pierwsza rewizja przedmiotu Chrześcijaństwo, religie i filozofie życiowe KRL (Kristendoms- religions- og livssynskunnskap) była w 2002 roku. Zmniejszono wtedy liczbę punktów edukacyjnych, uproszczono zasady dotyczące zwolnień i zmieniono nazwę. Departament Edukacji wydał broszurę, $\mathrm{w}$ której zebrano wszystkie dokumenty, które stanowiły formalny program przedmiotu oraz przedstawił interpretacje i wytyczne, w jaki sposób należy je wdrożyć.

2. Krytyka ze strony Komitetu Praw Człowieka ONZ spowodowała drugą rewizję KRL w 2005 roku. Uszanowano prawa rodziców do religijnego wychowania swoich dzieci. Zmiana ta była również powiązana z reformą promocji wiedzy, zmianą struktury sylabusów dla wszystkich przedmiotów. Modyfikacja z roku 2005 obejmowała zmianę ustawy o edukacji.

Leganger-Krogstad opisuje edukację religijną w Norwegii z 2005 roku jako:

wspólny, obowiązkowy, wieloreligijny przedmiot szkolny. Głównym celem jest przekazanie wiedzy o poglądach religijnych i światopoglądowych, aby dać wszystkim uczniom wspólny punkt odniesienia, aby umożliwić funkcjonowanie w społeczeństwie norweskim. (...) Celem jest zarówno potwierdzenie tożsamości jednostki zgodnie z jej/jego pochodzeniem, jak i przekazanie wiedzy i zrozumienia, które umożliwiają wnikliwy dialog ${ }^{41}$.

Termin niewyznaniowy oznacza tutaj formę, której celem jest uwolnienie się od religijnego wprowadzenia lub wychowania do określonej wiary.

${ }^{40}$ M.H. Bråten Oddrun, Towards a Methodology for Comparative Studies, s. 89-90.

${ }^{41}$ L.L. Iversen, Learning to be Norwegian, s. 107. 
W języku norweskim słowo konfesjonelt obejmuje zarówno „wyznaniowe”, jak i konfesyjne. Natomiast, w kraju tym wyznania chrześcijańskie inne niż Kościół Norweski (protestancki) były bardziej marginalne w społeczeństwie.

Dyskusje na temat edukacji religijnej były skoncentrowane wokół prawa:

- społeczeństwa (do określenia jego dziedzictwa kulturowego i określenia jego wartości);

- społeczności wyznaniowych (aby móc głosować w publicznej edukacji, aby stworzyć alternatywy?);

- rodziców (do decydowania o moralnym i religijnym wychowaniu ich dzieci);

- dziecka (być dobrze zorientowanym, zaangażowanym i krytycznym oraz wolnym od presji $)^{42}$.

3. Wyrok w Europejskim Trybunale Praw Człowieka zaowocował trzecią rewizją przedmiotu $\mathrm{w}$ roku 2008. Obejmowała ona zmiany w Ustawie o edukacji i nowej nazwie RLE - Religion, livssyn og etikk (Religia, poglądy życiowe i etyka). Zmiany dokonane $\mathrm{w}$ tym roku w przedmiocie były postrzegane jako bardziej drastyczne, duże, symboliczne, legalne i techniczne. Podkreślano, że edukacja religijna powinna być „krytyczna, obiektywna i pluralistyczna”.

Nastąpiła zmiana relacji między podmiotem a ogólnym określeniem wartości w pierwszym punkcie ustawy o edukacji. W końcu, co najbardziej kontrowersyjnie, centrolewicowy rząd zmienił nazwę na: Religia, poglądy życiowe i etyka. Po raz pierwszy w nazwie tej nie było wzmianki o chrześcijaństwie. Ministerstwo Oświaty i Badań było w czasach tych zmian kierowane przez partię socjalistyczną (partnera rządu na lewo od dominującej Partii Pracy). W debacie publicznej rząd został oskarżony o usunięcie "naszego dziedzictwa chrześcijańskiego", a z drugiej strony skrytykowany przez Europejski Trybunał Praw Człowieka, który stwierdził, że wprowadzone zmiany są jedynie kosmetycznymi i symbolicznymi zmianami ${ }^{43}$.

1 stycznia 2009 roku dokonała się ważna zmiana w norweskiej edukacji, ponieważ w ogólnych wytycznych podkreślono, że edukacja będzie oparta na podstawowych wartościach chrześcijańskich i humanistycznych, dziedzictwie i tradycjach, takich jak szacunek dla człowieka, życia i natury, wolności intelektualnej, ludzkości, tolerancji i solidarności, szacunku również dla wartości wyrażonych w różnych religiach, filozofiach życiowych i zakorzenionych w prawach człowieka ${ }^{44}$.

Po wyborach w 2013 roku negocjacje odnośnie nowej koalicji konserwatywnej objęły również problem edukacji religijnej. Partia Chrześcijańskich

${ }^{42}$ http://folk.uio.no/leirvik/OsloCoalition/Leirvik0902.htm

${ }^{43}$ L.L. Iversen, Learning to be Norwegian, s. 104-106.

${ }^{44}$ https://oda-hioa.archive.knowledgearc.net/ bitstream/handle/10642/2665/1242099 post.pdf? sequence $=2 \&$ is Allowed $=y$ 
Ludowców (KrF) zażądała wzmocnienia chrześcijaństwa w szkołach, ustalając czas jemu poświęcony na około połowę całkowitego czasu poświęconego na ten przedmiot i przywracając chrześcijaństwo do nazwy podmiotu, skąd zostało usunięte $\mathrm{w}$ ostatniej zmianie. W październiku 2013 roku Lider Partii Konserwatywnej, Erna Solberg, zgodziła się, że nazwa przedmiotu RLE zostanie zmieniona na: Chrześcijaństwo, religia, światopoglądy i etyka (Kristendom, religia, livssyn og etikk KRLE), a 55\% nauczania przedmiotu było zarezerwowane na tematy związane z chrześcijaństwem. Zostało to później zmienione na około połowę programu nauczania. Główną perspektywą modelu jest to, co Schreiner określa jako „podejście ponadnarodowe” do religii i światopoglądów ${ }^{45}$.

Propozycja wywołała masową debatę w mediach. Krytyka tej zmiany była bliska jednomyślności. Organizacje niereligijne, związki nauczycieli, badacze religii, a nawet kilku biskupów norweskiego Kościoła wyrazili dezaprobatę dla ponownej zmiany przedmiotu.

Jednak korekta została wprowadzona w sierpniu 2015 roku. Audun Toft twierdzi, że jednym z najważniejszych sprzeciwów wobec tej zmiany jest to, że nie wynika ona $z$ oceny sposobu, w jaki przedmiot jest w ogóle nauczany. Treść przedmiotu pozostaje niezmieniona tak, jak miało to miejsce w przypadku ostatniej zmiany w roku 2008. Skoro stary program nauczania dawał już chrześcijaństwu jakościowo największą część przedmiotu, to zmiana ta tak naprawdę nie wnosi niczego znaczącego, a tylko dalej przyczynia się do niepokojów i kontrowersji dotyczących religii w szkole ${ }^{46}$. Wzmacnia ona przekonanie, że nauczanie religii $\mathrm{w}$ szkole jest tematem delikatnym i stanowi możliwe źródło konfliktów. Ostatnie badania norweskiego nauczania religijnego w północnej i środkowej części Norwegii ${ }^{47}$ wskazują na dwie tendencje: niepokój i dystans. Niepokój ten jest najbardziej namacalny wśród nauczycieli identyfikujących się jako chrześcijanie. Doświadczają oni własnej tożsamości religijnej jako wyzwania dydaktycznego w klasie. Zaangażowanie $w$ poglądy religijne jest zgłaszane jako potencjalne źródło konfliktu, a nauczyciele chrześcijańscy w materiale decydują się na ukrycie swojej religijnej przynależności. Również religijne pochodzenie uczniów jest postrzegane jako problematyczne, a niektórzy nauczyciele twierdzą, że aktywnie unikają sytuacji, w których wyrażane są przekonania religijne uczniów. Ten niepokój wydaje się wpływać na sposób nauczania tego przedmiotu. Badanie wykazuje silną tendencję do pośredniego nauczania. Edukacja religijna uczy zatem tego, w co wierzą inni.

\footnotetext{
${ }^{45}$ Tamże.

${ }^{46} \mathrm{http}$ :/ / religiongoingpublic.com/archive/2016/religious-education-in-norway-distance-and-unease

${ }^{47}$ https://www.akademika.no/rle-i-klemme/fuglseth-kaare/9788232102525
} 
Pod pewnymi względami można powiedzieć, że jest to zgodne z programem nauczania, który podkreśla, że KRLE (Kristendom, religion, livssyn og etikk) jest zwyczajnym przedmiotem szkolnym, którego należy uczyć „bezstronnie i na podstawie faktów" 48 .

Od kilkudziesięciu lat dyskusja na temat wolności religii w Norwegii jest silnie związana z debatą na temat religijnej, a raczej chrześcijańskiej edukacji w szkołach publicznych ${ }^{49}$.

Obecnie $\mathrm{w}$ ramach nauczania religii prowadzony jest przedmiot: Chrześcijaństwo, religia, filozofia życia i etyka (Kristendom, religion, livssyn og etikk), który według założeń ma zapewnić obiektywne i bezstronne nauczanie o różnych religiach oraz filozofiach życia, a treści etyczne przedstawiane winny być z różnej perspektywy. Główne obszary religii, filozofii życia i etyki obejmują: chrześcijaństwo, judaizm, islam, hinduizm, buddyzm, filozofie życia, filozofię i etykę. Nauczanie religijne w Norwegii ma charakter niekonfesyjny, fenomenologiczny, chrześcijański. Przedmiot jest skonstruowany w głównych obszarach, które wzajemnie się uzupełniają i należy je postrzegać w kontekście: Chrześcijaństwo, religia, filozofia życia i etyka:

\begin{tabular}{|c|c|c|c|}
\hline Lata & \multicolumn{3}{|c|}{ Główne obszary } \\
\hline $1-7$ & $\begin{array}{c}\text { chrześcijań- } \\
\text { stwo }\end{array}$ & $\begin{array}{c}\text { judaizm, islam, } \\
\text { hinduizm, bud- } \\
\text { dyzm i filozofia } \\
\text { życia }\end{array}$ & $\begin{array}{c}\text { Filozofia } \\
\text { i etyka }\end{array}$ \\
\hline $8-10$ & $\begin{array}{c}\text { chrześcijań- } \\
\text { stwo }\end{array}$ & $\begin{array}{c}\text { judaizm, is- } \\
\text { lam, hinduizm, } \\
\text { buddyzm, inna } \\
\text { różnorodność } \\
\text { religijna i życie }\end{array}$ & $\begin{array}{c}\text { Filozofia } \\
\text { i etyka }\end{array}$ \\
\hline
\end{tabular}

Harmonogram podany w 60-minutowych jednostkach: szkoła podstawowa: 1 - 7. rok: 427 godzin; szkoła średnia: 8 - 10. rok: 153 godziny $^{50}$.

Głównym celem kształcenia w zakresie Chrześcijaństwa, religii, filozofii życia i etyki (KRLE) jest przedstawienie religii i filozofii życia, które

${ }^{48}$ http://religiongoingpublic.com/archive/2016/religious-education-in-norway-distance-and-unease

${ }^{49}$ Tamże.

${ }^{50}$ https://www.udir.no/k106/RLE1-02/Hele/Kompetansemaal/etter-4.-arstrinn [dostęp: 8.03.2018]. 
odzwierciedlają najgłębsze pytania ludzi, a poprzez historię pomogły kształtować jednostkę, społeczność i społeczeństwo. Znajomość religii i filozofii życia jest niezbędna dla jednostki, w celu interpretacji życia i zrozumienia kultur we własnym społeczeństwie i poza nim. Dzieci i młodzież napotykają dziś na wiele kulturowych wpływów i cenią tradycję. Wiara chrześcijańska i tradycja od wieków charakteryzują kulturę europejską i norweską. W tym samym czasie tradycje humanistyczne nadały dziedzictwu kulturowemu dalszy zakres. Różnorodność religijna i filozoficzna coraz bardziej wpływa na społeczeństwo. Znajomość różnych religii i filozofii życia, etyki i filozofii jest niezbędnym warunkiem wstępnym do interpretacji życia, świadomości etycznej i zrozumienia przekonań. Chrześcijaństwo, religia, filozofia życia i etyka jako edukacja ogólna powinny przyczynić się do stworzenia wspólnej bazy wiedzy i ram odniesienia, przyczynić się do nowych spostrzeżeń i umożliwić dialog dostosowany do różnych stopni wieku. Wiedza o religiach i filozofii życia oraz o funkcji, którą pełnią zarówno jako tradycję, jak i obecne źródła wiary, moralności i interpretacji życia, jest głównym przedmiotem ${ }^{51}$.

Kurs zapewnia znajomość chrześcijaństwa, innych światowych religii i filozofii oraz zagadnień etycznych i filozoficznych, który daje wgląd w znaczenie chrześcijaństwa jako dziedzictwa kulturowego dla społeczeństwa norweskiego. Mniej więcej połowa czasu nauczania w tym przedmiocie zostanie wykorzystana na chrześcijaństwo. Chrześcijaństwo, religia, filozofia życia i etyka to zwykły przedmiot szkolny, który gromadzi zazwyczaj wszystkich uczniów. Ustawa o edukacji zakłada, że nauczanie musi być obiektywne, krytyczne i pluralistyczne. Lekcje nie mogą być okazją do realizowania praktyk religijnych, ewangelizacji. W programie zwraca się uwagę na odpowiedni dobór metod pracy i obiektywne podejście do różnych religii w celu zapewnienia szacunku dla uczniów o innych wyznaniach i ich rodzin ${ }^{52}$.

W Norwegii obserwujemy obecnie systematyczny rozdział państwa od Kościoła i działania w edukacji na rzecz społeczeństwa wielokulturowego. Ścisłe do niedawna związki formalne instytucji władzy z Kościołem, umocowane konstytucyjnie, nie stanęły na przeszkodzie we wprowadzaniu zmian w edukacji religijnej. Ważne jest również stałe podkreślanie osadzonych w chrześcijaństwie korzeni społeczeństwa norweskiego, a z drugiej strony - odpowiedź na zmiany społeczne spowodowane migracją i pluralizmem religijnym.

\section{BIBLIOGRAFIA}

Bagrowicz J., Edukacja religijna wspótczesnej młodzieży. Źródła i cele, Torun 2000.

Bråten Oddrun M.H., Towards a Methodology for Comparative Studies in Religious Education. A Study of England and Norway, Munster, New York - Munchen - Berlin 2013.

Church of Norway, https://www.ssb.no/en/kultur-og-fritid/statistikker/kirke_kostra [dostęp: 10.04.2018].

\footnotetext{
51 Tamże.

52 Tamże.
} 
Egeland J.O., Gud som valgflesk https://www.dagbladet.no/kultur/gud-som-valgflesk/ 68533849 [dostęp: 10.04.2018].

Flugseth K., RLE i klemmeein studie av det erfarte RLE-faget https:/ / www.akademika.no/ rle-i-klemme/fuglseth-kaare/9788232102525 [dostęp: 16.06.2017].

Friestad E., Første gang: Flertall tror ikke på Gud, https://www.vl.no/nyhet/forste-gangflertall-tror-ikke-pa-gud-1.702540?paywall=true [dostęp: 11.05.2018].

Gunnarsson Gunnar J., From religious homogeneity to secularization, diversity and pluralism, Nordidactica, 2017, 1.

Hovdelien O., Education and Common Values in a Multicultural Society - The Norwegian Case, Journal of Intercultural Studies, 2015, 36(3) https://oda-hioa.archive.knowledgearc. net / bitstream/ handle/10642/2665/1242099 post.pdf? sequence=2\&isAllowed=y [dostęp: 14.04.2018].

https:/ / widget-last-free-article.herokuapp.com/?desktop=true [dostęp: 11.05.2018].

https://www.britannica.com/biography/Erik-Pontoppidan [dostęp: 14.04.2018].

http:/ / www.evrel.ewf.uni-erlangen.de/pesc/ie-2008-skeie.pdf [dostęp: 14.04.2018].

https://www.udir.no/k106/RLE1-02/Hele/Kompetansemaal/etter-4.-arstrinn [dostęp: 8.03.2018].

Iversen L.L., Learning to be Norwegian, A case study of identity management in religious education in Norway, Munster, New York - Munchen - Berlin 2012.

Jacobsen C.M., Norway, [w:] Islam in the Nordic and Baltic Countries, red. G. Larsson, London 2009.

Joron P., Etno-Nationalizm and Education, [w:] Paradoxes of Cultural Recognition. Perspectives from Northen Europe, red. S.A. Sharam, E.Th. Hylland, G. Halleh, Burlington 2009.

Leirvik O., The current debate about religious education and freedom of religion in Norway. http://folk.uio.no/leirvik/OsloCoalition/Leirvik0902.htm [dostęp: 14.04.2018].

Mańkowska A., Religia w Norwegii - spojrzenie na wspótczesne społeczeństwo i edukację, KERYKS, 2012, 11/12/13.

Religious communities and life stance communities, https:/ / www.ssb.no/en/kultur-og-fritid/ statistikker/trosamf [dostęp: 11.05.2018].

Roesdahl E., Historia Wikingów, Gdańsk 1996.

Różańska A., Edukacja religijna młodzieży w warunkach pluralizmu religijnego w wybranych krajach Europy Środkowo-Wschodniej (Grupa Wyszehradzka: Polska, Czechy, Stowacja, Węgry) - studium porównawcze, Torun 2015.

Sakowicz E., Wychowanie w kulturach i religiach świata, [w:] Dzieci z trudnościami adaptacyjnymi w młodszym wieku. Aspekty rozwojowe i edukacyjne w kontekście specyfiki różnic kulturowych, red. E. Śmiechowska-Petrovska, Warszawa 2016.

Sandnes T. (red.), Innvandrere $i$ Norge 2017, Oslo - Kongsvinger 2017, https:/ /www.ssb. no/en/befolkning/artikler-og-publikasjoner/_attachment/332154?_ts=1604a8c12b0 [dostęp: 15.12.2017].

Skeie G., Diversity and the political function of religious education, British Journal of Religious Education, 2006, 28(1).

Sødal H.K., Eidhamar L.G., Religion in Norway, A bird's-Eye View, [w:] Norway. Society and Culture, wyd. II, red. E. Maggerø, B. Simonsen, Kristiansand 2008.

Søgård T., Troen på Gud dør langsomt ut https:/ / www.dt.no/kultur/nyheter/troen-pa-gud-dor-langsomt-ut/s/2-2.1748-1.5145740 [dostęp: 11.05.2018].

Storhaug H., Islam, Jedenasta plaga, Stapis, Katowice 2015.

Toft A., Religious Education in Norway: Distance and Unease, http:/ / religiongoingpublic.com/ archive/2016/religious-education-in-norway-distance-and-unease [dostęp: 16.06.2017]. 